IJ§ER

ISSN: 2149-5939
International Journal of Social Sciences and Education Research

Online, https://dergipark.org.tr/tr/pub/ijsser

Volume: 6(2), 2020

Research Article

\title{
Impact of corona crisis on SMEs in the Slovak Republic
}

\author{
Katarína Belanová ${ }^{1}$
}

Received date: 17 / 05 / 2020

Accepted date: $28 / 06 / 2020$

\begin{abstract}
The current situation related to the spread of coronavirus in Slovakia is a burdensome test for everyone. Its effects will be felt mostly by entrepreneurs from the category of small and medium-sized enterprises and sole proprietors. Small and medium-sized enterprises are a pillar of the Slovak economy. The aim of the article is to point out the initial impacts of corona crisis on SMEs in the Slovak Republic and to propose measures to mitigate its negative consequences. We present that $8.9 \%$ of entrepreneurs out of all active small and medium-sized enterprises had to close their operations in a period of extraordinary situation. Even the part of entrepreneurs who continued in their activities and have not closed operations (57\%) has a big problem with the declining demand for their products and services.
\end{abstract}

Keywords: Small and medium - sized enterprises, corona crisis, financial support

\section{Introduction}

In Slovakia, small and medium-sized enterprises (SMEs) are a key segment of the business sector, as well as the backbone of the economy and the basis for the country's competitiveness.

SMEs in the SR are defined according to the European Commission Recommendation $2003 / 361$, which sets out the main factors for determining whether a company is a SME; number of employees and either turnover or balance sheet total. We can recognize three categories of enterprises: Micro (less than 10 employees, turnover or balance sheet total $\leq 2$ million EUR), Small (less than 50 employees, turnover or balance sheet total $\leq 10$ million EUR), Medium-sized (less than 250 employees, turnover $\leq 50$ million EUR or balance sheet total $\leq 43$ million EUR).

A favorable business environment is an important prerequisite for their successful development. After a relatively long period of prosperity connected with GDP growth and low unemployment, there was a reversal this year.

The coronavirus, which was confirmed in Slovakia in March 2020, has also had a huge impact on the business environment and the economy. Regarding this, a corona crisis has started. Although it is very complicated to predict future development under the current uncertain conditions, it can already be stated that the effects of the corona crisis will be felt mostly by small and medium-sized enterprises and sole proprietors.

As part of measures to prevent the spread of coronavirus, selected retail and service facilities were closed in Slovakia. The paper points out that quarantine measures have significantly affected

1 Assoc.prof. Ing. Katarína Belanová, PhD., University of Economics in Bratislava, Slovakia, katarina.belanova@euba.sk 
Belanová, K. (2020). Impact of corona crisis on SMEs in the Slovak Republic. International Journal of Social Sciences and Education Research, 6(2), 150-156.

small and medium-sized enterprises, who started to have problems with cash flow and maintaining employment due to the economic downturn.

The aim of the article is to point out the initial impacts of corona crisis on SMEs in the Slovak Republic and to propose measures to mitigate its negative consequences on SMEs.

Figure 1 EU - 28 and Slovakia GDP Annual Growth Rate (\%)

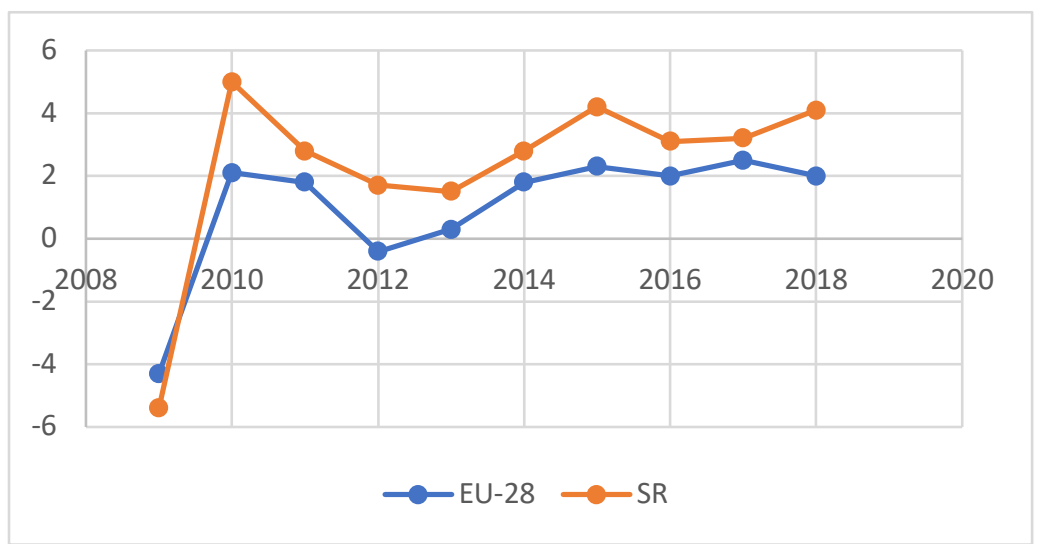

Source: Eurostat

Figure 2 Development of unemployment rate in the SR

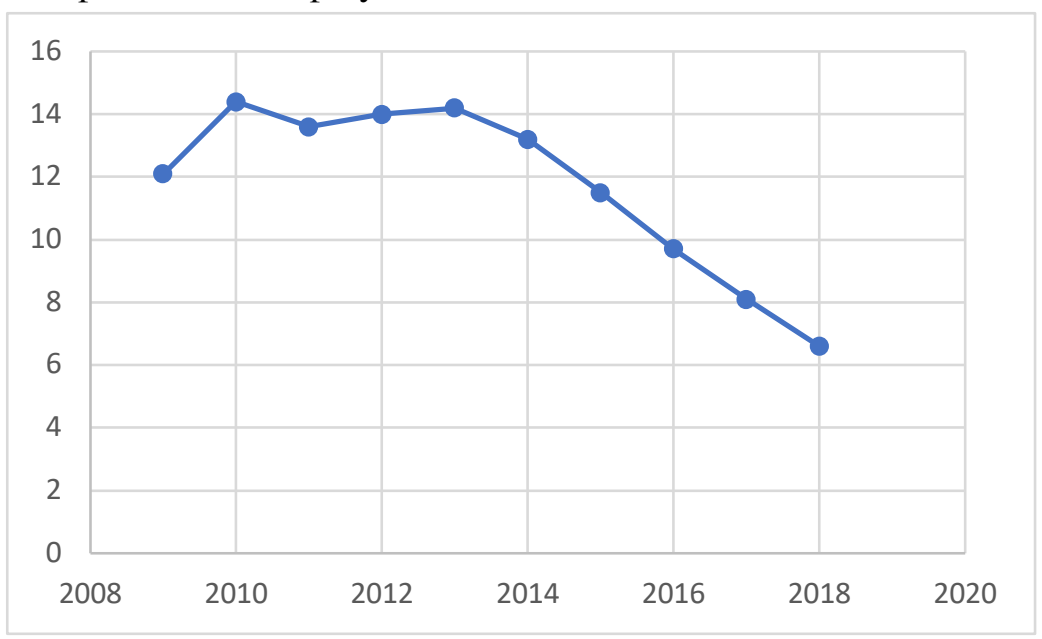

Source: The Statistical Office of the Slovak Republic

\section{Literature}

The business environment of SMEs is the subject of many foreign (Berger and Udell, 1995; Berry et al., 2004; Cressy andOlofsson, 1997; Degryse and Cayseele, 2000; Dierkes, 2013) and domestic scientific works (Belanová, 2018; 2019). They conclude that due to the economic and social importance that SMEs represent for the Slovak economy, it is necessary to improve the business environment for their development.

Regarding the overcoming negative effects of corona crisis, it will be especially important to improve, resp. to make their access to external sources of finance easier.

The OECD report (OECD Scoreboard, 2016) states that the most common source of external financing for SMEs is bank credit. SMEs are usually at a disadvantage in obtaining bank loans 
Belanová, K. (2020). Impact of corona crisis on SMEs in the Slovak Republic. International Journal of Social Sciences and Education Research, 6(2), 150-156.

compared to large, established firms. This is related to their smaller size, lower diversification, limited market and higher risk. As Covaci (2008) states, SMEs are generally more risky than large companies because they are more sensitive to economic shocks and have lower ability to absorb change. This makes them more difficult, respectively completely impossible to use bank loans. From many other authors, this is confirmed by research of Berger and Udell (2002), respectively, Prevan and Kuvek (2014), who asserted that smaller and younger companies have bigger problems with external financing and pay higher prices. For this reason, SMEs rely on internal or "personal" funds, they are increasingly suffering from information asymmetry problems and have a low internal rate of return.

In Slovakia, SMEs are primarily financed from own sources of financing, resp. from external sources they mainly use bank account overdrafts, leasing and bank loans (EC and ECB, 2018). Although the results of the EC and ECB survey (2018) pointed to a continuous improvement in SMEs' access to finance in a pre - crises period, even within individual EU-28 countries access to SME finance in Slovakia is considered to be the least significant problem, SMEs from Slovakia achieve worse results in obtaining bank loans. Facilitating lending will be even more necessary in overcoming the corona crisis.

\section{Methodology}

To point out the initial impacts on SMEs in the Slovak Republic we described the development of SMEs in the Slovak Republic. We used the data from the Statistical Office of the Slovak Republic. The impacts of the corona crisis were presented by the use of two surveys realized by the Slovak Business Agency (2020) and The Slovak Craft Industry Federation (2020). We used analysis to process the data and make conclusions.

\section{Development of SMEs in the Slovak Republic}

The number of small and medium-sized enterprises is one of the basic quantitative indicators characterizing the state of the SME sector.

In 2018, similarly to previous years, small and medium-sized enterprises accounted for $99.9 \%$ of the total number of business entities in the Slovak economy. In a year-on-year comparison, their number decreased by $1.3 \%$. Of the total number of enterprises, $96.8 \%$ were micro-enterprises $(542,525), 2.6 \%(14,328)$ small enterprises and $0.5 \%(2,988)$ medium-sized enterprises and $0.1 \%$ (680) large enterprises. Due to their achieved share, the position of the category of micro-enterprises in Slovakia is more significant in comparison with the EU countries. In recent years, the number of micro-enterprises has fluctuated around $97 \%$ of the total number of business entities. In the monitoring year 2018, their number decreased slightly (by 1.4\%), which was mainly due to a decrease in the number of active self-employed persons, as well as the transfer of business entities to higher categories of enterprises (with a higher number of employees). In 2018, a positive trend was recorded in the number of established small and medium-sized enterprises, while in the year-on-year comparison their number increased by almost one fifth (19.4\%), resp. to 78,075 entities.

The most significant was the year-on-year increase in self-employed persons. Another positive fact in 2018 was a decrease in the number of defunct business entities by $0.8 \%$, resp. to 52,168 entities. The net increase in business entities was double compared to the previous year $(25,907$ business entities). The position of women in the business sector in Slovakia did not change 
significantly even in 2018. The development of the age structure of natural persons - entrepreneurs has recently been characterized by an increase in the representation of entrepreneurs in the younger age categories of less than 30 years. On the contrary, after the previous increase, in 2018 the representation of natural persons - entrepreneurs aged 60 and over is decreasing. In the observed period, most entrepreneurs were in the age category from 30 to 49 years.

Compared to 2017, employment in the SME sector increased by $1.4 \%$, value added by $11 \%$, while the achieved year-on-year growth was the most significant in the last 8 years. The generated profit before tax increased by $18.4 \%$ year-on-year and the gross production of SMEs by $7.8 \%$. According to the preliminary results of the Statistical Office of the Slovak Republic, the year-onyear growth rate of SME exports also increased by 3.6\%. Despite the positive development within several indicators, small and medium-sized enterprises failed to follow the previous positive development in the area of investment activity. The decline in the volume of investment even before the outbreak of the corona crisis pointed to a possible slowdown in the economic performance of SMEs in the future.

More than three quarters (76.4\%) of small and medium-sized enterprises in Slovakia carried out their main business activity in the following four sectors: business services, trade, construction and industry. The share of other sectors in the monitored category of SMEs did not exceed $10 \%$, while in the long run the lowest share is shown by the agricultural sector (4.1\%) together with the accommodation and catering sector (3.3\%).

Figure 3 Slovakia's regions

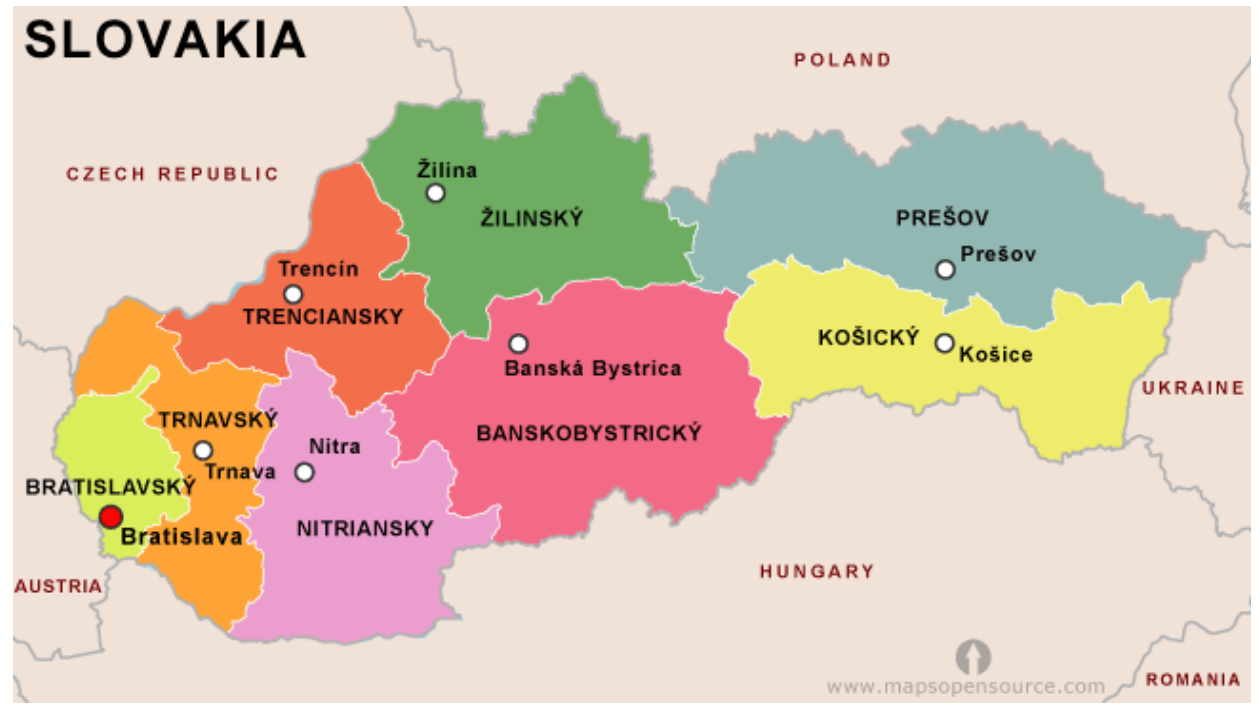

The long-term development of the sectoral structure of SMEs is characterized by a growing representation of the services sector, which is accompanied by a decline in the trade sector.

The rate of business activity of SMEs reached $20.4 \%$. Compared to other EU countries, Slovakia ranks among the countries with the highest number of small and medium-sized enterprises in terms of total population. The structure of SMEs according to legal forms is still dominated by natural persons - entrepreneurs with a share of $59.0 \%$, despite the continuous decline in their representation. The share of SMEs - legal entities in the total number of SMEs reached $41.0 \%$. The number of active natural persons - entrepreneurs decreased by $5.2 \%$ year-on-year in 2018 to 330,377 entrepreneurs. The total number of small and medium-sized enterprises - legal entities increased by $4.9 \%$ to 229,464 entities. The highest share of individual legal forms of SME-legal 
Belanová, K. (2020). Impact of corona crisis on SMEs in the Slovak Republic. International Journal of Social Sciences and Education Research, 6(2), 150-156.

entities was achieved by limited liability companies (91.6\%), which are also characterized by dynamic growth in number and long-term.

The regions of western and northern Slovakia are generally characterized by a higher rate of business activity, while a low rate of business activity is achieved in eastern Slovakia and the south of central Slovakia.

\section{Result and conclusion}

Thanks to the coronavirus impulse, the current crisis has a number of specific features that distinguish this crisis from standard cyclical crises. The primary specificity of the corona crisis is state measures aimed at protecting the health of the population, which are accompanied by a forced restriction of certain economic activities.

As the results of the Monitoring Business Environment survey (2020) show, according to the SK NACE classification, a total of 53,243 small and medium-sized enterprises operate in Slovakia in the sectors most at risk of quarantine measures. These entities, which were forced to close their operations, make up $8.9 \%$ of the total number of active small and medium-sized enterprises.

Micro-enterprises employing less than 10 employees dominate in the total number of most vulnerable SMEs. They reach 96.2\% share. Representation of small enterprises (10-49 employees) represents $3.4 \%$ and medium-sized enterprises (50-249 employees) $0.4 \%$.

Self-employed people predominate in the structure of endangered SMEs according to individual legal forms. Self-employed persons make up almost two thirds (59.7\%) of the total number of vulnerable SMEs. More than one third (37.4\%) is represented by the share of enterprises (legal entities) and $2.9 \%$ of persons doing business in the form of liberal professions.

Quarantine measures required the closure of establishments operated by small and mediumsized enterprises in the areas of retail trade, accommodation and food service activities, transport and business and other services.

In retail trade, furniture traders (720 SMEs), computers (691) and second-hand goods (598) had to limit their business. In the accommodation and catering sector, the most endangered are entrepreneurs providing dining type catering (6,962 SMEs), other special-purpose catering establishments $(4,371)$ and restaurants $(3,885)$. Entrepreneurs providing other passenger land transport $(3,485$ SMEs) and taxi services $(2,193)$ in particular have existential problems in the transport sector. Entrepreneurs in business services, such as travel agencies (623 SMEs) and travel agencies (507), also have to deal with a complex situation. Most small and medium-sized enterprises, which had to reduce their business due to quarantine measures, operate in the area of other services (37.0\%). The main activities of these entrepreneurs are, for example, the provision of hairdressing and beauty services (11,195 SMEs), well-being services $(3,267)$, or entertainment and leisure activities $(1,489)$.

The most endangered small and medium-sized enterprises carry out their activities in the Bratislava Region (22.9\%). The representation of other regions ranges from 9.5\% (Trenčín Region) to $12.0 \%$ (Prešov Region). Small and medium-sized enterprises, which had to limit their business, achieved sales of EUR 6.8 billion in 2018 from the sale of their goods and services. The value added of these entities amounted to EUR 1.3 billion. Table 1 presents the summary resulting from Monitoring Business Environment survey. 
Belanová, K. (2020). Impact of corona crisis on SMEs in the Slovak Republic. International Journal of Social Sciences and Education Research, 6(2), 150-156.

Table 1 Frequency of SMEs operating in sectors most endangered by the coronavirus

\begin{tabular}{|l|l|l|}
\hline Legal form & number & $(\%)$ \\
\hline Enterprises - legal entities & 19,931 & 37.4 \\
\hline Self - employed & 31,785 & 59.7 \\
\hline Liberal professions & 1,527 & 2.9 \\
\hline Size & number & $(\%)$ \\
\hline Micro & 51,212 & 96.2 \\
\hline Small & 1,810 & 3.4 \\
\hline medium & 221 & 0.4 \\
\hline Sector & number & $(\%)$ \\
\hline Retail trade & 4,187 & 7.9 \\
\hline Accommodation and food service & 19,419 & 36.5 \\
\hline Transport & 7,884 & 14.8 \\
\hline Business & 1,478 & 2.8 \\
\hline Other services & 20,275 & 38.1 \\
\hline Region & number & $(\%)$ \\
\hline Bratislava & 12,213 & 22.9 \\
\hline Trnava & 6,175 & 11.6 \\
\hline Trenčín & 5,046 & 9.5 \\
\hline Nitra & 6,243 & 11.7 \\
\hline Žilina & 6,348 & 11.9 \\
\hline Banská Bystrica & 5,546 & 10.4 \\
\hline Prešov & 6,408 & 12 \\
\hline Košice & 5,264 & 9.9 \\
\hline Totally & 53,243 & 100.0 \\
\hline
\end{tabular}

Source: Monitoring Business Environment survey (2020)

The Slovak Craft Industry Federation, the Entrepreneurs Association of Slovakia in cooperation with the Wilio.sk platform, conducted a survey (2020) to map the current situation of selfemployed persons and small entrepreneurs. Its aim was to find out the economic effects of the measures taken to prevent the spread of the corona virus and what form of help this group of entrepreneurs needs the most.

The results of the survey showed that up to $54 \%$ of respondents lost their jobs due to customers canceling orders due to restrictions associated with the transmission and spread of the disease. Another $25 \%$ were forced to suspend their activities due to the adopted state regulations and $11.5 \%$ did so voluntarily, which means that up to $36 \%$ of self-employed and small entrepreneurs have their activities interrupted altogether. Only $9.2 \%$ of respondents have only minor impacts on their business.

Even the part of entrepreneurs who continue their activities and have not closed operations (57\%) has a big problem with the declining demand for their products and services, and only a small part (4.4\%) stated that their services are required more than before beginning of the restriction. The availability of materials and long delivery times also seem to be a problem.

Entrepreneurs had the opportunity to express in the survey which form of aid they would currently appreciate the most. As many as $55 \%$ of respondents need subsidies for fixed operating costs, as they have to pay even if they have no income. Another expected form of assistance from the state is the deferral of repayments of social and health contributions, as well as the deferral of loan repayments. State aid in connection with the coronary crisis is constantly evolving. The conditions for individual state contributions are being updated, and new laws regulating (not only) the financial area are being approved. 
Belanová, K. (2020). Impact of corona crisis on SMEs in the Slovak Republic. International Journal of Social Sciences and Education Research, 6(2), 150-156.

All measures approved so far in Slovakia are called "LEX KORONA" and are presented to the public gradually, through aid packages. The First Aid package was intended for SMEs, other rounds are also intended for larger enterprises, very intensive work is being done especially on the introduction of the so-called Kurzarbeit in Slovak legislation and the use of special assistance from the EU.

We can conclude, that measures to mitigate the effects of a coronavirus pandemic have been taken, in which measures to facilitate SMEs' access to finance have a special role to play. Especially facilitating lending will be even more necessary in overcoming the corona crisis. State aid in connection with the coronary crisis is constantly evolving. The conditions for individual state contributions are being updated, and new laws regulating (not only) the financial area are being approved. Measures need to be "tailor-made" for SMEs.

\section{References}

Belanová, K. (2018). SMEs in the Slovak Republic and Their Innovative Activity. SEPIKE 2018: Social Educational Project of Improving Knowledge in Economics: Innovations in the Modern World. Frankfurt : Association 1901 SEPIKE. ISBN 9783-7481-8504-8, pp. 35-59.

Belanová, K. (2019). Public Sources in Finance of Innovative Small and Medium-sized Enterprises in the SR. Organizational-Economic Mechanism of Management Innovative Development of Economic Entities : Collective Monograph in 3 Vol.. - Przeworsk : Wyższa Szkola Społeczno-Gospodarcza. ISBN 978-83-937354-6-4, pp. 124-142.

Berger, A. and Udell, G. (1995). Relationship Lending and Lines of Credit in Small Firm Finance. Journal of Business, 3, pp. $351-382$.

Berger, N. A. and Udell, F. G. (2002). Small Business credit Availability and Relationship lending. The Economic Journal, 112(477), F32-F53.

Berry, A. - Grant, P.- Jarvis, R. (2004). European Bank Lending to the UK SME Sector, An Investigation of Approaches Adopted. Intenational Small Busness Journal, 22(2), pp.115 - 130.

Covaci, B. (2008). Credit Risk in Financing SME in Romania. Bucharest: SpiruHaret University.

Cressy, R. and Olofsson, Ch. (1997). European SME Financing. Small Business Economics, 2, pp. 87 - 96.

Degryse, H. and Van Cayseele, P. (2000). Relationship lending within a Bank-based system: Evidence from European small business data. Center of Economic Studies, Discusion Paper Series DPS 98.16.

Dierkes, M. et al. (2013). Business credit intormation sparing and default risk of private firms. Journal of Banking \& Finance, Vo. 37, pp. 2867-2878.

ECB (2018). Survey on the Access to Finance of Enterprises in the euro area. Retrieved from https://www.ecb.europa.eu/stats/ecb_surveys/safe

Monitoring of Business Environment. (2020). Analysis of SMEs directly endangered by pandemics. Retrieved from: http://monitoringmsp.sk/2020/03/31/analyza-msp-priamo-ohrozenych-pandemiou/

OECD. (2016). Financing SMEs and Entrepreneurs 2016: An OECD Scoreboard, OECD Publishing, Paris. Retrieved from: http://dx.doi.org/10.1787/fin_sme_ent-2016-en

Pervan, I. and Kuvek, T. (2013). The relevant Importance of Financial Ratios and NonFinancial variables in Predicting of Insolvency. Croatian Operational research review, 4, 187-197.

Slovak Craft Industry Federation (2020). More than 93\% of entrepreneurs were affected by coronavirus. Retrieved from: https://www.szZ.sk/images/Articles/PDFka/06-04-2020-TS-Prieskum-WILIO_SZZconverted.pdf 